\title{
Risk Management for Qatar Expressway Program
}

\author{
Nor Rozaini Abd Rahman \\ nabdrahman@ashghal.gov.qa \\ Public Works Authority (Ashghal), Doha, Qatar
}

\begin{abstract}
The construction of expressway projects associated with the various main risks such as political risks, legal risks, economic risks, cultural risks, and construction risks are considered critical and essential to be identified and mitigated in early stage for every minor or major projects. According to Dziadosz and Rejment (2015), the risk is a measurable part of uncertainty, for which we are able to estimate the occurrence probability and the size of damage. The risk is assumed as a deviation from the desired level. It can be positive or, which most often happens, it can be negative. Therefore, the risks analysis is so important for project selection and coordination of construction work. This paper identifies the level of severity of construction risks which had affected the implementation of the expressway/highway projects in Qatar. This research is also focused on the importance in practising the formality of risk management process by identifying the problems and difficulties associated with the projects risks, which includes obtaining the important information and suggestion the risk response in order to be used on future projects in the particular and focusing the risk mitigation in the early stage is necessary. There could be a possibility that the identified projects were not fully assessing the significant risk factors during feasibility studies, design stage, tender stage and construction stage. Based on a literature review, structured interviews with experts, unstructured interviews and detailed case studies, it was found that major participants agreed that the risk management process was satisfactorily adopted for ongoing and previous infrastructure projects in Qatar. The critical construction risk was design changes, new requirements, land acquisition, interfacing works and additional works which had caused the cost overrun and delay the completion works.
\end{abstract}

Keywords: Construction risk; Risk management; Risk mitigation; Expressway projects; Qatar

\section{INTRODUCTION}

A high quality highway network system has always been one of the prerequisites for a country to organize any large international events including sporting championships or tournaments. Public Works Authority (PWA or ASHGHAL) is responsible to undertake the implementations and completion of expressway program which covering the North, South, Central, Northwest and Orbital networks approximately 900 kilometre of mainline carriageway, major interchanges, bridges, tunnelling works, bypass includes new and upgraded expressways with value of USD8.1 billion within limited time frame. According to Zou et al. (2007), "managing risks in construction projects has been recognized as a very important management process in order to achieve the project objectives in terms of time, cost, quality, safety and environmental sustainability." 


\section{PROBLEM STATEMENT}

The majority of respondents agreed that the project risks caused the cost overrun and delaying the completion of works. Potential construction risks need to be identified in early stage of construction, and the mitigation risks need to be incorporated in the project risks management process.

\section{RESEARCH OBJECTIVE}

This research began with the objectives of identifying of construction risks in highway projects based on the on-going and completed projects, the followings objectives were highlighted:

i. To determine the most critical and extreme construction risks which need to be addressed on priority basis.

ii. To define the mitigation risks in early stage of construction works.

\section{RESEARCH METHODOLOGY}

\subsection{Questionnaires}

The data obtained from the literature review and one case study had provided a basis for designing the questionnaires, which were distributed into fifty (50) experts i.e. focusing on the Civil Engineers, Quantity Surveyors and Contract Specialist from PWA. The questionnaires have also been forwarded to the PWA's Project Management Consultant (PMC) staff. Out of fifty (50) experts who were approached directly by the researcher either by hand or by electronic mail, only 31 responses were received, giving a success rate of 62 per cent.

\subsection{Structured Interviews and Unstructured Interviews}

Structured Interviews participants were selected and conducted only for the experts who were involved directly in implementation of expressway projects. Some of the questions from the same questionnaires were used to explore more on the construction risk and mitigation plan being implemented in their projects. Ten (10) interview sessions involving middle to upper management from PWA were carried out between October and November 2019.

\subsection{Detailed Case Study}

The researcher choose one mega highway project (Project A) which had associated with massive interfacing works particularly when dealing with another key project stakeholders. Project A case was studied and analyzed to determine the construction risks, level of risk involved and to capture the relevant information, obstacles and challenges. And whether the project risk management process had been carried out during the implementation works.

\section{FINDINGS}

\subsection{Case Study of Highway Project}

Compared with many other industries, the construction industry is subject to more risks due to the unique features of construction activities, such as long period, complicated processes, abominable environment, financial intensity and dynamic 
organization structures (Flanagan \& Norman, 1993; Akintoye \& MacLeod, 1997; Smith, 2003; Zou et al., 2007). The scope of works for Project A involved with reconstruction and upgrading the existing highway including interchanges that consisted of tunnels, underpasses, flyover, junctions and two marine bridges. This project also involved with the construction of the Light Rail Transit (LRT), tunnel extension and massive utilities diversions. The characteristics for this mega project as shown on Table 1 indicated that the huge additional amount increased $30 \%$ of the original contract sum and Extension of Time (EoT) for 1503 days.

Table 1: The Characteristics of Project A

\begin{tabular}{|l|l|l|l|}
\hline Original Contract Sum & \multicolumn{1}{l}{$3,574,234,000.00$} & \multicolumn{1}{l}{ Start Date } & 21-May-12 \\
\hline Variation Order (VO) & $1,135,860,000.00$ & Original Completion Date & 18-Sep-15 \\
\hline Percentage of VO & $32 \%$ & Delays to contract & 1503 Days \\
\hline Revised Contract Sum & $4,710,094,000.00$ & Revised Completion Date & 30-Oct-19 \\
\hline
\end{tabular}

\subsection{Risk Identification of Highway Projects}

According to Dziadosz and Rejment (2015), "at the stage of identification we should get the statement of the factors, which are possible to occur in the whole cycle of the project. The most frequently mentioned methods/tools used to identify risk factors are the following: the brainstorming, the Delphic technique, the check-lists, the experts' evaluation, the internal audit in a company, the periodic document reviews, etc." Project Risk identification in this paper is based on one (1) case study i.e. Project A and the feedbacks from the respondents which will be discussed later under the topic of "the Ranking of Severity Impact of the Construction Risks for Highway Projects" in page 4. The risk assessment is developed in order to identify the level of project risk which had affected Project A by approaching the risk management methods i.e. "Risk Matrix" model for analysis the likelihood of occurrence and the impact.

Table 2: Risk Matrix for Project A case study

\begin{tabular}{|c|c|c|c|c|c|c|c|c|}
\hline \multirow[b]{2}{*}{ Descriptions of Construction Risks } & \multirow[b]{2}{*}{ Probability } & \multicolumn{5}{|c|}{ Cost Impact \& Time Impact (Prolongation Cost) } & \multirow{2}{*}{$\begin{array}{l}\text { Total } \\
\text { Score }\end{array}$} & \multirow{2}{*}{$\begin{array}{c}\text { Level of } \\
\text { Risk }\end{array}$} \\
\hline & & $\begin{array}{c}\text { score } \\
5 \\
\end{array}$ & $\begin{array}{c}\text { score } \\
4\end{array}$ & $\begin{array}{c}\text { score } \\
3\end{array}$ & $\begin{array}{c}\text { score } \\
2\end{array}$ & $\begin{array}{c}\text { score } \\
1\end{array}$ & & \\
\hline Design Changes & 4 & $\begin{array}{c}300- \\
500 \text { mil }\end{array}$ & & & & & 20 & Extreme \\
\hline New requirements & 4 & & $\begin{array}{c}50-100 \\
\text { mil }\end{array}$ & & & & 16 & Extreme \\
\hline Land acquisition & 4 & & & $\begin{array}{c}20-50 \\
\text { mil }\end{array}$ & & & 12 & High \\
\hline Interfacing Works & 4 & & & $\begin{array}{c}20-50 \\
\text { mil }\end{array}$ & & & 12 & High \\
\hline Additional scope of works & 4 & $\begin{array}{c}300- \\
500 \mathrm{mil}\end{array}$ & & & & & 20 & Extreme \\
\hline Non Performance of the contractors & 3 & & & $\begin{array}{c}20-50 \\
\text { mil }\end{array}$ & & & 9 & High \\
\hline $\begin{array}{l}\text { Availability of materials, labors and } \\
\text { machineries }\end{array}$ & 2 & & & & $\begin{array}{c}5-20 \\
\text { mil }\end{array}$ & & 4 & Medium \\
\hline $\begin{array}{l}\text { Physical geography and soil } \\
\text { conditions }\end{array}$ & 2 & & & & $\begin{array}{c}5-20 \\
\mathrm{mil}\end{array}$ & & 4 & Medium \\
\hline $\begin{array}{l}\text { Blockade from neighboring } \\
\text { countries }\end{array}$ & 2 & & & & $\begin{array}{c}5-20 \\
\text { mil }\end{array}$ & & 4 & Medium \\
\hline $\begin{array}{l}\text { Fluctuation of labor \& Materials } \\
\text { price }\end{array}$ & 1 & & & & & $\begin{array}{c}0-10 \\
\text { mil }\end{array}$ & 1 & Low \\
\hline
\end{tabular}


The probability is derived from opinion, judgement and personal experiences from the experts, detail Variation Orders (VOs) submission and Monthly Project Reports. To ensure the accuracy of the cost impact, the input is based on VOs submission and VOs' trackers. The total score as shown in Table 2 is justified the level of severity on the project risks. Based on total score for project A as shown in Table 2 and Figure 1 indicated that a likelihood of occurrence for "Design Changes", "New Requirements" and "Additional Scope of Works" are almost certain/frequently which the event occurs many times during the construction period. In addition, the cost impact for those extreme categories level of risks also had severely affected cost overrun to project A.

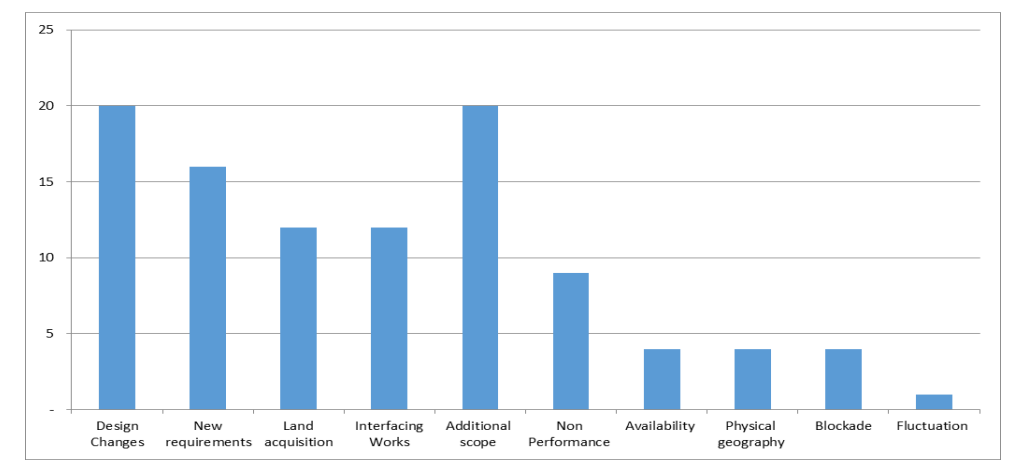

Figure 1: Total Score and Level of Construction Risk for Project A

\subsection{The Ranking of Severity Impact of the Construction Risks for Highway Projects}

The result is established based on thirty one (31) respondents out of fifty (50) questionnaires been circulated among the experts as listed in Table 3. In order to categorize the ranking for the level of risk, the researcher developed a method by multiplying the number of respondents to the score number. Based on this approach hierarchical ranking of construction risks in Table 3 shown that the "Design Changes" as the most severe construction risk, followed by the "New Requirements", "Land Acquisition", Non Performance of Contractors" and "Interfacing Works" which were tremendously impacting the cost overrun and caused the delay for the completion of highway projects in Qatar.

Table 3: Level of Severity Impact of the Construction Risk for highway projects in Qatar

\begin{tabular}{|c|l|c|c|c|c|c|c|}
\hline No & \multicolumn{1}{|c|}{$\begin{array}{c}\text { Descriptions of Construction } \\
\text { Risks }\end{array}$} & $\begin{array}{c}\text { Extreme } \\
\text { score } \\
4\end{array}$ & $\begin{array}{c}\text { High } \\
\text { score } \\
3\end{array}$ & $\begin{array}{c}\text { Medium } \\
\text { Score } \\
2\end{array}$ & $\begin{array}{c}\text { Low } \\
\text { score } \\
1\end{array}$ & $\begin{array}{c}\text { Total } \\
\text { score }\end{array}$ & Ranking \\
\hline 1 & Design Changes & 14 & 15 & 2 & 0 & 105 & 1 \\
\hline 2 & New Requirements & 7 & 18 & 6 & 0 & 94 & 2 \\
\hline 3 & Land Acquisition & 14 & 7 & 6 & 4 & 93 & 3 \\
\hline 4 & Interfacing Works & 4 & 17 & 10 & 0 & 87 & 5 \\
\hline 5 & Additional Scope of Works & 4 & 17 & 9 & 1 & 86 & 6 \\
\hline 6 & Non Performance of the Contractors & 6 & 15 & 9 & 1 & 88 & 4 \\
\hline 7 & Availability of Materials, Labors \& Machineries & 3 & 15 & 11 & 2 & 81 & 7 \\
\hline 8 & Physical Geography and Soil Conditions & 3 & 5 & 15 & 8 & 65 & 9 \\
\hline 9 & Blockade from Neighboring Countries & 3 & 10 & 13 & 5 & 73 & 8 \\
\hline 10 & Fluctuation of Labor \& Materials Price & 3 & 1 & 18 & 9 & 60 & 10 \\
\hline
\end{tabular}




\subsection{The Implementation of Project Risk Management for Expressway Projects (On-Going and Completed)}

The respondents and interviewees are construction industry practitioners, including project managers, senior consultants, senior quantity surveyors and engineers, and top management personnel (i.e. managers and senior associate). They had an average of 15 to 25 years' work experience in the construction sector. The senior positions, long work experience and tertiary educational background infer that the respondents have adequate knowledge of construction projects and the associated risks. Based on their experiences being involved in expressway projects, the experts are requested to rating the implementation of risk management process for on-going and completed expressway projects. Major respondents justified that 29 percent is considered "satisfactory" as stated in Figure 2.

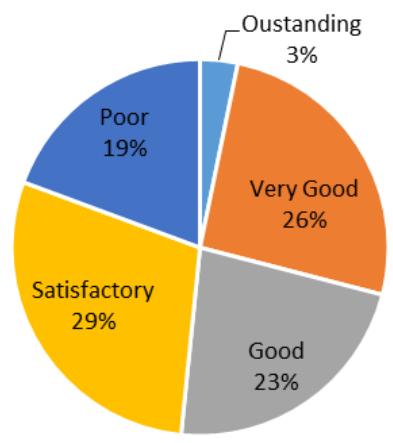

" Oustanding " VeryGood " Good " Satisfactory "

Figure 2: Distribution of respondents on justification, the project risk management had been practiced for on-going and completed highway projects

\section{RISK MITIGATIONS FOR HIGHWAYS PROJECTS}

Risk mitigation is an action to be implemented but not limited to other option i.e. risk avoidance, risk acceptance, risk eliminate, risk reduce, risk transfer or combination of two or three methods in reducing the risks that had been identified. In addition, each risk needs to be ranked on a scale of probability/occurrence and severity/impact to the projects. Based on the ranking result, level of priority also needs to be considered to mitigate the likelihood of the occurrence or the impact of that particular event. The identified project risk need to be incorporated in the risk register with risk mitigation plan or action should be taken in order to mitigating the risk as shown in Table 4.

Table 4: Risk Register compilation of construction risk that had been identified for expressway program in Qatar

\begin{tabular}{|c|c|c|}
\hline Risk/Issue & Effect & Mitigation/Action \\
\hline \multicolumn{3}{|l|}{ Design Changes } \\
\hline $\begin{array}{l}\text { Discrepancy between Storm Water Contract Drawings \& } \\
\text { PWA standard Drawings }\end{array}$ & $\begin{array}{l}\text { Delay \& time consuming to correct } \\
\text { the mistakes and cost impact. }\end{array}$ & $\begin{array}{l}\text { Accuracy and consistency of information in between } \\
\text { Contract Drawings, Construction Drawing \& PWA } \\
\text { standard drawings. Coordination between design team } \\
\text { and construction team. }\end{array}$ \\
\hline $\begin{array}{l}\text { Clash of existing Potable water with proposed Portable water, } \\
\text { Medium Voltage (MV), Lower Voltage (LV) existing foul } \\
\text { sewer, feeder } 1 \& 266 \text { kilovolt (kV) }\end{array}$ & $\begin{array}{l}\text { Design error due to absence of } \\
\text { structural calculations on water } \\
\text { chambers and thrust blocks caused } \\
\text { project disruption. }\end{array}$ & $\begin{array}{l}\text { PMC and consultants should be instructed the contractor } \\
\text { under specified clause to produce the calculations. }\end{array}$ \\
\hline
\end{tabular}




\begin{tabular}{|c|c|c|}
\hline \multicolumn{3}{|l|}{ Interfacing Works - Stakeholders } \\
\hline $\begin{array}{l}\text { Delay in submission of wall design due to lack of Design } \\
\text { certificate, and CAT } 3 \text { certificate. }\end{array}$ & $\begin{array}{l}\text { Delay in getting approval and } \\
\text { disruption to the construction works }\end{array}$ & $\begin{array}{l}\text { Expedite the processes in order to obtain the Design } \\
\text { certificate and others certificates. }\end{array}$ \\
\hline $\begin{array}{l}\text { As built document/drawings submission had not been } \\
\text { progressed as per plan due to design issues, uncompleted } \\
\text { works and insufficient resources. }\end{array}$ & $\begin{array}{l}\text { Delay in getting approval, caused } \\
\text { interfacing works and disruption to } \\
\text { the construction works }\end{array}$ & $\begin{array}{l}\text { Accurate and sufficient design information. Expedite } \\
\text { the progress of works and the submission of As Built } \\
\text { document/drawings. Alternative resources need to be } \\
\text { arranged. }\end{array}$ \\
\hline $\begin{array}{l}\text { Delay to securing Ministry of Municipality and Environment } \\
\text { (MME). Permit to construct the Site Compound Facilities } \\
\text { (Precast/Laydown/hall/workshops, etc.) }\end{array}$ & $\begin{array}{l}\text { Delay in getting approval, caused } \\
\text { delay and disruption to the } \\
\text { construction works }\end{array}$ & $\begin{array}{l}\text { Consultant to continue to liaise with PWA to determine } \\
\text { status of submission and clarification to reduce review } \\
\text { process and approval times prior to MME requirements. }\end{array}$ \\
\hline \multicolumn{3}{|l|}{ New Requirements } \\
\hline $\begin{array}{l}\text { Approval from General Electric (Kahramaa) for new } \\
\text { substation including the permit }\end{array}$ & $\begin{array}{l}\text { Delay in getting approval, caused } \\
\text { delay and disruption to the } \\
\text { construction works }\end{array}$ & $\begin{array}{l}\text { Contractor/Consultant to expedite with Kahramaa the } \\
\text { approval of shop drawings and obtain building permit } \\
\text { from MME. }\end{array}$ \\
\hline \multicolumn{3}{|l|}{ Non Performance of the Contractors } \\
\hline $\begin{array}{l}\text { Contractor's rate of progress on remaining utility works } \\
\text { remain slow }\end{array}$ & Delay in completion works & $\begin{array}{l}\text { The contractors are advised to increase their supervisory } \\
\text { staff and manpower. }\end{array}$ \\
\hline Design work had not been approved yet & $\begin{array}{l}\text { Delay in getting approval, caused } \\
\text { delay and disruption to the } \\
\text { construction works }\end{array}$ & $\begin{array}{l}\text { Contractor to expedite final design work and obtain } \\
\text { approval from various stakeholders. }\end{array}$ \\
\hline \multicolumn{3}{|l|}{ Land Acquisition } \\
\hline $\begin{array}{l}\text { Land Acquisition/Demolition permits was pending for hand } \\
\text { over/approval }\end{array}$ & $\begin{array}{l}\text { Unable to purchase/own land will } \\
\text { cause delay, design changes and } \\
\text { prolongation cost also will be } \\
\text { claimed by the contractors. }\end{array}$ & $\begin{array}{l}\mathrm{PWA} / \text { Consultant/contractor will need to coordinate } \\
\text { with the owner/organizations in order to expedite the } \\
\text { handover of the related area. }\end{array}$ \\
\hline \multicolumn{3}{|l|}{ Physical Geography and Soil Conditions } \\
\hline Unforeseen conditions - damage the utilities & $\begin{array}{l}\text { Damage works are required the } \\
\text { rectification works which caused } \\
\text { delay and disruption to the } \\
\text { construction works. }\end{array}$ & $\begin{array}{l}\text { The contractor will be requested to confirm the location } \\
\text { and levels of those utilities before the commencement of } \\
\text { the works }\end{array}$ \\
\hline
\end{tabular}

\section{RECOMMENDATION}

\subsection{Feasibility Study Stage}

Based on the structured interview sessions, the author justified that the construction risks for certain project in the expressway program was not properly identified, evaluated and resolute during feasibility study due to the limited time frame. For example, land acquisition issues should be resolved at the early stage before started the construction works. Apart of detail study, adequate ample period of time is essential during feasibility study for focusing potential construction risk which probably will be disrupted the construction works. Risk transfer by shifting the risk to the competent contractor using the right contract strategy particularly "Design and Build" also considered as a strategic option.

\subsection{Cost Estimate and Contingency}

The design changes, new requirements and additional works had caused the variation orders, which particularly required an additional budget. Most scenarios, the provisional sum and contingency were insufficient to cover the increased cost of actual work done. Cost estimation process is essential to obtain the accuracy of the overall project cost. Therefore, the accuracy of information, rates, scope of works, method of statements, specifications need to be detailed and updated. Engineering design department, stakeholders and PWA requirements, and business support department are responsible for providing the accurate input and information of design factors in order to ensure that an estimator is capable to convert the information and design into the preparation of BoQ. Moreover, to make sure for allocating sufficient provisional sum and contingency. Oberlender (2000) stated that engineering and construction are risk endeavours with many uncertainties, particularly in the early stages of project development. Contingency 
is assigned based on uncertainty and may be assigned for many uncertainties, such as pricing, escalation, schedule, omissions, and errors. The practice of including contingency for possible scope expansion is highly dependent on the attitude and culture, particularly that of the business unit, toward changes.

\subsection{Design Coordination}

Design changes due to design deficiencies take time to correct, and the design errors is leading to variations, ambiguities, major project challenges and will be delayed the progress of works. According to Zou et al. (2007) stated that "Design variations" were popularly arisen in the design phase of a project and may result from issues such as "variations by the client" and defective designs. To avoid defective design, the design team need not only to fully understand what the clients want as defined in the project brief, but also to establish an efficient communication scheme among the designers." Establishing Engineering Design department consisting of building, road, drainage, sewerage, highway, etc. under one roof is necessary and definitely will mitigate conflicts amongst the design team.

\subsection{Blockade/Embargo Issues}

Political risk can be defined as "the risk of probability of occurrence of some political event that will change the prospects for the profitability of a given investment" (Haendel, 1979; Chua, Wang \& Tan, 2003; Abd Rahman et al., 2009). The contractors had submitted the claims to PWA in order to claim the increasing material prices due to the sudden political blockade that happened in June 2017. However, PWA had been specified clearly in General Condition of Contract $(\mathrm{CoC})$ that, "in the event the contractor is unable to source and acquire materials and equipment from countries stated "in the approved manufacturers/suppliers/vendor list due embargo, the contractor shall source and acquire equivalent materials and equipment from other alternative countries accordingly if required without addition cost incurred to PWA."

Unforeseen political risk such as blockade/embargo which need to be seriously managed from top management to the bottom level. PWA and counterparts such as other ministry needs to demonstrate some proactive measures and must lead to minimize the risk and addressed to overcome the impact of material shortages as not to affect the work progress of on-going or future project.

\subsection{Strategic Alliances}

Identify the primary motivations for organizations to enter strategic alliances to be risk sharing, product rationalization and economics of scale, transfer of complimentary technology/exchange of patents, shaping competition, facilitating international expansion, conformance to host government policy, and vertical linkages (Glaister et al., 1998; Fellows \& Liu, 2009). Apart some organizations are focusing to explore/ sharing technology by forming a strategic alliances, another option/reason is to ensure better supply of materials and equipment by considering having a "trading partner" as opportunities particularly for construction firms to create and manage a healthy supply chain, risk reduction and to ensure the project success. 


\section{CONCLUSION}

Based on a project case study analysis, result from questionnaires and the interview sessions with the experts, the results could be justified that the risk management process had been culturally adopted for the previous and on-going projects under the expressway program. However, for certain projects, the risk management implementation including risk mitigations had been approached actively only during the construction stage. Proper risk management processes need to be implemented during the beginning of the projects particularly started from the feasibility study stage and design stage. Project risks need to be identified, ranked the level of risk severity and registered. Furthermore, prioritized the extreme risks, mitigated and managed efficiently. ASHGHAL has its own Risk Management Department and started to adopting the risk management practice currently and also for future infrastructure projects. Apart from risk management department, by establishing the interfacing department in future also could be a strategic solution for managing the interfacing risk. Instead of to ensure that the interfacing matters are identified, assessed for potential clashes and resolutions, the potential interfacing risk for every project could be identified, mitigated, updated and controlled sufficiently.

\section{REFERENCES}

Abd Rahman, N. R., Torrance, J. V. \& Torrance, M. H. (2009). Influential factors impacting international construction. The Case of Malaysian Contractors, Joint Ventures in Construction, Kobayashi, K., Abdul Rashid, K., Ofori, G., Ogunlana, S. \& Thomas Telford, London, 90100.

Dziadosz, A. \& Rejment, M. (2015) Risk analysis in construction project - chosen methods. Operational research in sustainable development and civil engineering - meeting of EURO working group and 15th German-Lithuanian-Polish colloquium (ORSDCE 2015): Procedia Engineering, 122 (2015), 258-265.

Fellows, R. \& Liu, A. M. M. (2009). Construction projects as joint ventures: Issues of culture and risk, joint ventures in Construction. Kobayashi, K., Abdul Rashid, K., Ofori, G., Ogunlana, S. \& Thomas Telford, London, 17-29.

Oberlender, G. D. (2000) Project management for engineering and construction, Thomas Casson, the USA.

Zou, P. X. W., Zhang, G. \& Wang, J. Y. (2007). Identifying key risk in construction projects: Life cycle and stakeholder perspectives. Journal of Project Management, 25 601-614. 